\title{
REBRANDING SOUTHEAST ASIA
}

\author{
Hanafi Hussin \\ Department of Southeast Asian Studies \\ Faculty of Arts and Social Sciences \\ Institute of Ocean and Earth Sciences (IOES) \\ University of Malaya \\ (hanafih@um.edu.my) \\ Doi: https://doi.org/10.22452/jati.sp2018no1.1
}

\begin{abstract}
Southeast Asia with different geographical landscapes and inhabited by diversities of people with unique cultures and recognize as Asian cultural mosaic and branding this region as a fast growing in many aspects, politics, economy, infrastructure and cultural development. The region is sharing development concept, the knowledge-based economy and the global environment, strongly followed branding and rebranding strategies to garner more economic benefits. No doubt that the region is also facing a great challenge from internal and external factors and the region from time to time need to review their internal and external policies. All policies towards economics, politics and social enable an individual country in Southeast Asia change the outlook of the country in facing the external world like Malaysia. It will affect the relations and cooperation bilaterally, regionally and globally especially diplomatic, international relations and economic relations. The possible and broader questions related to the concerns could be how these were reframed and rebranded to benefit countries and what were the impacts of rebranding on cultures, norms, values, practices and traditional lifestyles? All these issues were discussed at the $7^{\text {th }}$ International Conference on Southeast Asia (ICONSEA 2017). This will discuss a selected paper presented in this conference in line with the main theme of the conference rebranding Southeast Asia.
\end{abstract}

Keywords: rebranding, Southeast Asia, ASEAN, Southeast Asian Studies, ICONSEA2017, social-politics, culture and economy 


\section{Introduction}

Within Asia and the world, Southeast Asia comprising of eleven countries is the most stunning regions with unique landscapes and inhabited by diversities of people with unique cultures. Southeast Asia is recognized as Asian cultural mosaic which continues to brand itself as a unique region as rapidly growing in many areas. It has branded itself as a centre for politics, economy and cultural development with the emergence of some spectacular urban centres, stimulated by recent massive economic growth and different levels of socio-economic developments.

The convergent impacts of globalization, the increasing importance of knowledge as the principal driver of growth, revolution of the ICT, and also competitive education have become unprecedented challenges that a must-faced by Southeast Asian region. Education is a paramount significant and strategic for developing human resources in the main force of every country's development especially in terms of economic development. Over the last half-century, the growth economies of partly of the mainland and insular Southeast Asia particular in the country of - Indonesia, Malaysia, the Philippines, Singapore, Thailand, and Vietnam - have transformed themselves into middle-income countries. At one side point of view, it brings prosperity to Southeast Asia, and on the other hand, this breed new challenges, problems, and tensions. As the brand then becoming on the top of the market, time and market demands changes may lead to the decline of brand's images and force the company to make some rebranding on the existing brand to sustain their demands in the market. In facing many major challenges, the Southeast Asian nations must double their productivity to see continued economic growth to make each country in the region become stronger and unite as one big community. This will make Southeast Asia stable in many aspects especially socio-economy, sociocultural and socio-politics.

\section{Literature review}

\section{Branding and rebranding}

A product (or service) becomes a brand through a process, which shapes an exceptional image, name and identity of the product in people's mind (Biedenbach, 2017). The making of the brand often done through campaigns and advertisements. The prime purpose of branding is to create an essential and unique presence of the product in the market, which could attract, collect and retain the loyal customers (Business Dictionary, n.d.). A successful brand is a 
combination of name, design, and symbol of a product, which makes the product visible, identifiable and sustainable in the market (Doyle, 1994). A brand is also a combination of calculated cultural and economic ideas (Grant, 2006). Nation brands are founded on the national identity, which possesses more productive and cultural resources than any other types of brands, such as product brands or corporate brands (Dinnie, 2016). Brands become icons through creative interaction with their environment in a process that he termed as a 'cultural branding,' a process that he considered particularly suitable for applying to nations (Holt, 2012).

Most of the enterprises, whether small or large, have to brand their services and products because branding is the most effective brand strategy that helps the business to get an edge over other brands in the competitive markets (Huber, 2011). In a branding strategy, three ' $W s^{\prime}$ and one ' $\mathrm{H}$ ' are taken into consideration that includes how, when, where and to whom to communicate and deliver the message of a brand (product or service). It focuses on where to promote and publicize the message, which distribution channels have to be engaged and visual and verbal use of the content (Kaira, 2015). Strategic branding with continuity makes strong brand equity, which implies that the added value came to a company's services or products, gives the company to charge more money as compared to identical but unbranded products and services (Nedeljkovic-Pravdic, 2010; Buyong \& Rajiani, 2011). From a cultural perspective, a country could be seen as a brand. Cultural forces play a role in building iconic brands and bring ing the lasting impact of branding practices on other cultures and markets in which the brand is viewed as an integral part of and supplier to mainstream culture (Heding, Knudtzen, \& Bjerre, 2009).

By using culture and identity as part of branding approaches, food heritage is used as one of the tools of tourism product to promote Malaysia and enhance its tourism industry. The adaptation of food from various ethnic groups by the dominant or majority ethnic group in multi-racial and cultural nations is believed to commonly acceptable cuisines and longitudinally forming the national food identity (Ramli \& Zahari, 2015). Rebranding is also a process like the branding itself. In it, it reshapes or reformulates the name, image, and identity of a service, product, organization, culture and country. The rebranding is done to meet customers, the markets and global economies changing needs and demands (The Economic Times, n.d.; Daly \& Moloney, 2005). Rebranding implies that the managers have taken a serious strategic decision and have carefully planned to discard or change the long held name or identity (Daly \& Moloney, 2005). Not only a company but a country or nation could also rebrand itself (Fan, 2006; Mackay \& Swift, 2012). 


\section{Discussion}

In contemporary Southeast Asia, changes in the global economy and education systems and approaches have attracted the attention of many academics, scholars, researchers, etc. to discuss many issues pertaining to rebranding Southeast Asia through development paths, reframes Asia's model(s) of growth and draws out the social, environmental, political and economic side-effects that have arisen from growth. An interesting analysis of the problems that come alongside the development's achievements. Many of the issues arose from the development, branding and rebranding of products, services, companies and nations have been discussed at the 2017 International Conference on Southeast Asia organized by the Department of Southeast Asian Studies, Faculty of Arts and Social Sciences, University of Malaya. The discussion around the rebranding concept was done in the regional and local (national) contexts. All the themes of discussion in the conference were related to emerging Southeast Asia/ASEANTheoretical and conceptual, Security, economy, identity, maritime Southeast Asia, citizenship, multiculturalism, heritage, tourism, religion and religiosity, language and linguistics, literature and arts, education, community engagement, challenges of Southeast Asian studies, etc.

\section{Southeast Asia as a dynamic region}

It seems trendy in contemporary Southeast Asia to discuss the institutions in Southeast Asia and issues related to these. ASEAN is one of the institutions, which received more attention of the scholars to discuss it from rebranding perspective. For example, Sharifah Nur Syafiqah Binti Syed Omar, Thirunaukarasu Subramaniam, Mazlan Majid and Nanthakumar Loganathan used ASEAN-3 as a frame of reference to discuss their research findings on female fertility in Indonesia, Thailand and the Philippines from 1980 until 2014. ASEAN also always been highlighted in the discourses related to international relations, security, strategic planning, economy and many more among the topics of attracting the discussion. Ali Jibran in his paper is looking at the prospects of ASEAN in improving Malaysia-Indonesia relations. Jibran suggested that ASEAN can prove a platform to improve mutual relations between Malaysia and Indonesia because working more closely within the framework of ASEAN will cause a spillover effect in socio-political and security related areas between Malaysia and Indonesia.

This regional Association proved as a good agency to promote peace and stability and also promoting good relations and cooperation to enhance and strengthen diplomatic and economic relations. Nazariah Osman and Muhammad 
Muda claimed that Malaysia's commitment in championing the interests of the developing countries took centre stage in the nation's foreign policy and can see Malaysia's major initiative in assisting the developing countries through the South-South Cooperation has resulted in the establishment of the Malaysian Technical Cooperation Program (MTCP) with its main objective is to achieve sustainable economic and social development among them. By doing so, Malaysia will be known and remembered for its dedication to assisting fellow developing nations that are too keen to emulate Malaysia's socio-economic success and it will help Malaysia to be one of a developed nation by 2020 . Therefore, Malaysia will be rebranded.

\section{Complexity Southeast Asia reflected in Southeast Asian nation - Malaysia}

In facing the challenges world in many aspects to achieve as a developed nation, efforts in various aspects need to be done to position the country at par with the nations. Malaysia for example, taking many steps to achieve this goal like branding the country for tourism, repositioning the cultural setting and development which involving its people and the communities. Hanafi Hussin indicated that promoting the country in the world map as an important and strategic tourist destination with the slogan 'Malaysia Truly Asia' proven a successful branding Malaysia as a tourism spot. Razan Rosman and Sarena Abdullah discuss the cosmopolitan Malay of Malaysia through visual imageries in the1930s which grown accustomed to the modern lifestyle, espoused by their cosmopolitan appearance and outlook. By highlighting Abdullah Ariff as 'Father of Modern Art in Malaysia' Sarena Abdullah captured the works of Abdullah Ariff this co-called cosmopolitan Malays having a modern style of living.

One of the indicators of a certain country has achieved its sustainability development the commitment of the government in enhancing and empowering community economic development. Community engagement is proved the best way of getting commitment and participation of the government and nongovernment agencies in the development of the community. Wan Izatul Asma Wan Talaat looks at how conserving marine resources could involve the local community. By taking the existing marine conservation efforts in Terengganu, she pointed out that factoring in the local communities' engagement through collaborative management to enhance this effort and expecting fishermen's lifelong knowledge and livelihood could help them face the challenges of sustaining development.

Malaysia is growing very well in the economic sector through many programs as discussed earlier. On the other hand, Malaysia is also facing a great challenge with from internal and external treat which could affect the nation 
security. Extremist groups among contemporary treat which could affect very much of the trust local and foreigner who are visiting the country especially tourist. Ummu Atiyah Ahmad Zakuan discusses the issue of an extremist group in the country especially involving women in the Islamic State of Iraq and Syria (ISIS) which she labelled them as terrorist as well and the country should take precautious on this matter to ensure the continuous stability of the country.

\section{Conclusion}

The scholars have discussed various issues to highlight where and how things, images and policies could be improved and rebranded to bring improvement in the Southeast Asian economies and culture. The scholars also believed that besides rebranding economy, politics, culture, and interests, the academia should rebrand its approach to addressing the changing needs of society either in rural or urban areas. However, given the scholars strong concerns, we still need to understand, is it matter of rebranding the diverse the existing brands (i.e. political, social, cultural, economic and national) or is it an issue of redesigning the policies to benefit the larger groups of people especially marginalized and deprived groups living on the fringes of the society without justice, health and education services. Alternatively, is it simply to rebrand the image or tag in the media, or take practical measures for the larger interest of the region. It is up to the readers and the new researchers to decide which things suit to Southeast Asian region.

\section{References}

Biedenbach, G. (2017). Branding strategies: A stakeholder approach. In V. Tarnovskaya \& J. Bertilsson (Eds.), Brand theories: Perspectives on brands and branding (pp. 127-142. Lund: Studentlitteratur AB.

Business Dictionary. (n.d.). Branding. Retrieved from http://www.businessdictionary.com/definition/branding.html

Buyong, E., \& Rajiani, I. (2011). Cognitive and Affective Evaluation in Forming Unique Destination Image among Tourists Visiting Malacca. In Book of Proceeding: Brand, Identity and Reputation: Exploring, Creating New Realities and Fresh Perspectives on Multi-Sensory Experiences (p. 8). Oxford: Said Business School, University of Oxford Said Business School, University of Oxford. 
Daly, A., \& Moloney, D. (2005). Managing corporate rebranding. Irish Marketing Review, 17(1/2), 30-36.

Dinnie, K. (2016). Nation branding: Concepts, issues, practices. London: Routledge.

Doyle, P. (1994). Marketing Management and Strategy. Englewood Cliffs: PrenticeHall.

Fan, Y. (2006). Branding the nation: What is being branded?. Journal of vacation marketing, 12(1), 5-14.

Grant, J. (2006). The brand innovation manifesto: How to build brands, redefine markets and defy conventions. Chichester: John Wiley \& Sons Ltd.

Heding, T., Knudtzen, C. F., \& Bjerre, M. (2009). Brand management: Research, theory and practice. Abingdon: Routledge.

Holt, D. (2012). Cultural Brand Strategy. In G. Carpenter \& V. Shankar (Eds.), Handbook of Marketing Strategy (pp. 306-317). Cheltenham: Edward Elgar Publishing Limited.

Huber, A. J. (2011). Effective Strategy Implementation: Conceptualizing Firms' Strategy Implementation Capabilities and Assessing Their Impact on Firm Performance. Wiesbaden: Gabler.

Kaira, A. (2015). Brand Strategy: Company X. Undergraduate Thesis, Faculty of Business Administration, Saimaa University of Applied Sciences, Lappeen ranta, Finland.

Mackay, I., \& Swift, J. (2012). Warrior Nation: Rebranding Canada in an Age of Anxiety. Toronto: Between the Lines.

Nedeljkovic-Pravdic, M. (2010). How to create powerful brands-an investigation. Serbian Journal of Management, 5(1), 77-95.

Ramli, A. M., \& Zahari, S. M. (2015). The Determinant of Food Heritage in Malaysia Context. In S. Mohd. Radzi, N. Sumarjan, C. Tamby Chik, M. S. Mohd. Zahari, Z. Mohi, M. F. Saiful Bakhtiar \& F. I. Anuar (Eds.), Theory and Practice in Hospitality and Tourism Research (pp. 477-482). London: Taylor and Francis Group.

The Economic Times. (n.d.). Definition of rebranding. Retrieved from https://economictimes.indiatimes.com/definition/rebranding 